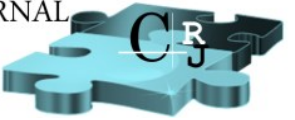

\title{
Go/NoGo continuous performance task in the
}

\section{psychophysiological research}

a Andrea Mestanikova, ${ }^{\mathrm{b}}$ Igor Ondrejka, a Michal Mestanik, ${ }^{\mathrm{b}}$ Igor Hrtanek, ${ }^{\mathrm{b}}$ Eva Snircova, a Ingrid Tonhajzerova a Department of Physiology, Jessenius Faculty of Medicine in Martin, Comenius University in Bratislava, Slovakia

b Clinic of Psychiatry, Jessenius Faculty of Medicine in Martin, Comenius University in Bratislava, Slovakia

Corresponding author:

Ingrid Tonhajzerova, $\mathrm{MD}, \mathrm{PhD}$

Associate Professor

Department of Physiology, Jessenius Faculty of Medicine in Martin, Comenius University in Bratislava, Slovakia

Malá Hora 4, 03601 Martin

Phone: ++421432633425

E-mail: ingridtonhajzerova@gmail.com ; tonhajzerova@jfmed.uniba.sk

\section{Abstract}

Introduction: Go/NoGo continuous performance task (CPT) is a neuropsychological test designed for measurement of attention and impulsivity and very often associated with attention deficit hyperactivity disorder (ADHD). The aim of this study was to provide current view of test with its application in future psychophysiological research and clinical practise.

Methods: The studies regarding CPT were collected using scientific databases (PUBMed, Medline, SCOPUS). The heart rate variability (HRV) as an index of parasympathetic activity and electrodermal activity (EDA) as a noninvasive index of sympathetic arousal were applied in ADHD and depression during Go/NoGo CPT.

Conclusion: In psychophysiological research, the altered HRV and EDA could represent a noninvasive biomarkers for internalizing/externalizing psychopathology. It seems that Go/NoGo CPT could be used as an important diagnostic tool in mental disorders, however future research is needed.

Key words: Go/NoGo continuous performance task, heart rate variability, ADHD, electrodermal response

Introduction

Stress can be generally defined as a response to demands (usually noxious) on the body (Selye, 1936) or as alterations in psychophysiological homeostatic processes (Burchfield, 1979). The stimulus disrupting homeostasis is called a stressor. Stressors may be divided into several categories: e.g. physical (e.g. heat, cold), metabolic (e.g. hypoxia, hypoglycemia) and mental stressors (e.g. public speaking) (Mravec and Zucha, 2006). Stress leads to various changes in nervous system and the complex effect of mental stress depends on cognitive processing by cortical (mainly orbitofrontal and medial prefrontal) areas in cooperation with limbic system (Mravec et al., 2009). Nevertheless, autonomic nervous system (ANS) is very sensitive to mental stressors and its reactivity has been shown associated with physical, behavioral and mental health symptoms (El-Sheikh et al., 2009; Obradovic et al., 2010). Therefore, the ANS reactivity is extremely sensitive to laboratory stressors, such as Stroop and the mental arithmetic tests. Mental stress alters immediately and completely the sympathetic/parasympathetic balance (Martinez-Lavin, 2007), and the effect depends on receptor type 
(McCorry, 2007). For example, active stress is linked with higher heart rate, mediated through $\beta$-adrenergic activation and passive stress causes changes in blood pressure predominantly through the activation of $\alpha$ receptors (Chi et al., 1993; Delahanty et al., 1996).

One of the examples of active mental stressor is Go/NoGo continuous performance task (Go/NoGo CPT), which is designed as a neuropsychological test to measure attention and impulsivity. In following proposal, we describe the characteristic of test.

\section{Variants of Go/NoGo CPT}

In the traditional Go/NoGo CPT, participants are instructed to respond rapidly, generally with a button-press, to presentation of Go stimuli only, and response inhibition is measured by the ability to appropriately withhold responding to NoGo stimuli. Several variations of Go/NoGo stimuli have been used in various studies, for example the faces with emotions (Yu et al., 2014), coloured circles and geometric shapes (Thomalla et al., 2014), airplanes (as Go stimulus) and bombs (as a NoGo stimulus) (Rubia et al., 2001), numbers (Nelson et al., 1998), as well as the letters or its auditory modalities (Shucard et al., 2008). The example of test using Go/NoGo paradigm with letters stimuli is the Conners'Continuous Performance Test (CCPT). Traditional CCPT requires the subject to press a computer key only after $\mathrm{X}$ is presented and the modern version - the CCPT-II requires subject to press the computer key immediately after every letter except the X (Conner, 2000).

The differences in Go/NoGo paradigms are not only in the stimuli but also in the task designs. More traditional is using a simple format of test with a single Go stimulus and single NoGo stimulus. The example of more complex design is a version of the task where $\mathrm{X}$ and $\mathrm{Y}$ are alternately presented on the screen, and there is a two-letter repeat, which is the NoGo signal: if $\mathrm{X}$ is presented, $\mathrm{Y}$ will become Go signal and $\mathrm{X}$ the NoGo signal, and vice versa (Garavan et al., 1999).

\section{The Go/NoGo parameters}

Performance efficiency is generally expressed in terms of correct detections, commission and ommission errors and reaction time (Table 1.). From the psychological context, the errors of omisssion are assumed to reflect symptoms of innattention, while errors of commisssion are supposed to reflect impulsivity (Barkley, 1991; Halperin et al., 1991). Computerized RT measures, as a valuable indicator of cognitive performance have gained renewed attention, because the recognition that reaction time variability (RTV) may convey unique information (Berkson and Baumeister, 1967; Barrett et al., 1986; Jensen, 1992). RTV has been discussed as a potentially important index of the stability/instability of an individual's nervous system ( Karalunas et al., 2014). Several studies have used standard deviation (SDRT) to quantify RTV (Geurts et al., 2009; Sinzig et al., 2008). Alternatively, RTV is calculated as a coeficient of variation: SDTR/mean RT or by ex-gaussian decomposition, in which $\tau$ reflect both the mean reaction time and standard deviation of the exponential portion of the distribution. However, the ideal metrics of RTV are not yet clear (Karalunas et al., 2014). 
Table 1. Standard evaluating parameters in Go/NoGO CPT

\begin{tabular}{|l|l|}
\hline Correct detection & $\begin{array}{l}\text { indicate the number of times the client } \\
\text { responded to the target stimulus }\end{array}$ \\
\hline Ommision errors & $\begin{array}{l}\text { indicate the number of times the target was } \\
\text { presented, but the client did not respond/click } \\
\text { the button }\end{array}$ \\
\hline Commision errors & $\begin{array}{l}\text { indicate the number of times the client } \\
\text { responded but no target was presented }\end{array}$ \\
\hline Reaction times (RT) & $\begin{array}{l}\text { this measure the amount of time between the } \\
\text { presentation of the stimulus and the client's } \\
\text { response }\end{array}$ \\
\hline
\end{tabular}

CPT seems to be helpful in differencial diagnosis of mental disorders, in which the ability to supress inappropriate and unwanted actions is impaired. The most notable is attention deficit/hyperactivity disorder (ADHD) (Barkley, 1997). Karalunas et al. (2014) in their meta-analyse of several studies found increased RTV among individuals with ADHD compared with typically-developing controls. Moreover, this parameter has correlated with measures of behavioral inattention (Nigg, 1999; Wahlstedt, 2009; Wahlstedt et al. 2009), and it has to correlate with hyperactivity-impulsivity in other study (Gomez-Guerrero et al., 2011). However, the application of CPT, in particular RTV as a specific diagnostic tool remains questionable and without general acceptation as a "gold standard“ in externalizing psychopatology (McGee, 2000; Gualtieri et Johnson; 2005). For example, higher RTV has been observed in other mental disorders such as autism (Verte et al., 2005), schizophrenia (Kaiser et al., 2008) and bipolar disorder with psychotic symptoms (Bora et al., 2006).

Physiological responses to Go/NoGo test

\section{Brain activation}

The Go/NoGo tasks are focused on executive functions, that refer to the ability to plan and execute behaviour (Simmonds et al., 2008). The ability to supress irrelevant stimuli or impulses is essential for normal thinking processes and ultimately for successful living. Inhibitory control of behaviour, composing of motor, emotional, cognitive, and social abilities, is phylogenetically one of the highest developed human self-control functions (Williams et al., 1999). The beginning of inhibitory abilities also marks an important milestone in cognitive development, and is considered as a characteristic of frontal lobe maturation (Diamond, 1990). Previous studies have investigated the neural correlates of response inhibition. For example, the human lesion studies 
demonstrated the involvement of the frontal cortex (Drewe, 1975; Godefroy and Rousseaux, 1996), with more specific localization of the superior medial (Drewe, 1975; Floden and Stuss, 2006; Picton et al., 2006) and right inferior prefrontal cortical areas (Aron et al., 2003; Chambers et al., 2006). Recent studies using an objective neuroimaging methods found frontal lobe activation during Go/NoGo CPT (Garavan et al. 1999; Rubia et al. 2001). However, localization within the frontal cortex varies across studies depending on the task specificity (Mostofsky et al., 2003). It seems that the simple format of Go/NoGo task is examination of response inhibition under conditions in which other cognitive/behavioral processes are minimized, while more complex designs of Go/NoGo task demand also short term/working memory. The studies using simple format of Go/NoGo task demonstrated activation in the presupplementary motor area (pre-SMA) bilateral occipital regions and the precuneus, and the studies using the complex format of CPT found activation in the pre-SMA, right middle/inferior frontal gyrus, bilateral inferior parietal regions, bilateral putamen, bilateral insula, right middle temporal gyrus, left fusiform gyrus and the left middle gyrus. Moreover, both simple and complex Go/NoGo tasks evoked the activity of the pre-SMA suggesting that recruitment of the pre-SMA is critical to response inhibition irrespective of the task demands (Simmonds et al., 2008).

\section{Autonomic nervous system}

As mentioned in the beginning, Go/NoGo CPT as a mental stressor leads to the ANS response and alters the sympathetic/parasympathetic balance. Moreover, the complex analysis of ANS during CPT are rare.

Heart rate variability-index of parasympathetic activity

Cardiac function is extremely sensitive to autonomic influences. The heart rate variability (HRV), i.e., the amount of the heart rate fluctuations around the mean heart rate, provides insight into the autonomic control of the heart and gives important information about cardiac sympathetic and parasympathetic interaction (Stein and Kleiger, 1999; Van Ravenswaaij-Arts et al., 1993). The mental arousal which follows a laboratory mental stress test produces a centrally induced shift of ANS balance towards the sympathetic activation associated with vagal withddrawal. Therefore, it can be used as an ideal model to study the magnitude and complex dynamics of heart rate autonomic regulatory inputs (Visnovcova, et al. 2014). HRV is traditionaly quantified by linear methods- time and frequency (spectral) domain analysis- providing the information about the heart rate variability magnitude and frequencies (Task Force, 1996). Spectral analysis of HRV allows to isolate the faster high frequency respiratory-coupled oscillations as an index of cardiac vagal function (Bertson et al., 1997; Martinmäki et al., 2006). Recently, nonlinear methods measuring qualitative characteristic of the cardiac time series, i.e. complexity, and other system dynamic features have been shown to be more suitable for a detailed description of heart rate autonomic control (Javorka et al., 2009; Porta et al., 2009). Moreover, series of neuroimaging studies have provided evidence that HRV has been related to the activity of the prefrontal cortex (Lane et al., 2009). Therefore, it is proposed that HRV is related to cognitive performance (Thayer et al., 2009), which was supported by findings that subject with high HRV had a significantly higher number of correct responses compared to subject with low HRV during Go/NoGo task (Hansen et al., 2003; Eisenberg and Richman, 2011).

In our study, we assessed HRV during Go/NoGo CPT in ADHD as an externalizing disorder, depressive patient as an internalizing disorder and control subject. Our protocol type sent two stimuli types, a target -green circle and non-target -red coloured letter. In control subject, HRV was decreased during test indicating a shift of ANS dynamic balance to vagal withdrawal and sympathetic arousal (Fig. 1). It indicates physiological response of autonomic flexibility and adaptability. On the other hand, we found different heart rate reactivity in mental disorders compared to controls indicating a potential alteration in cardiac autonomic flexibility in ADHD and 


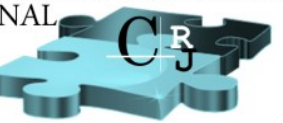

depression (Figures 2 and 3). It seems that HRV could represent an important predictive marker in psychophysiological research, however, this hypothesis is needed to validate in future longitudinal studies.

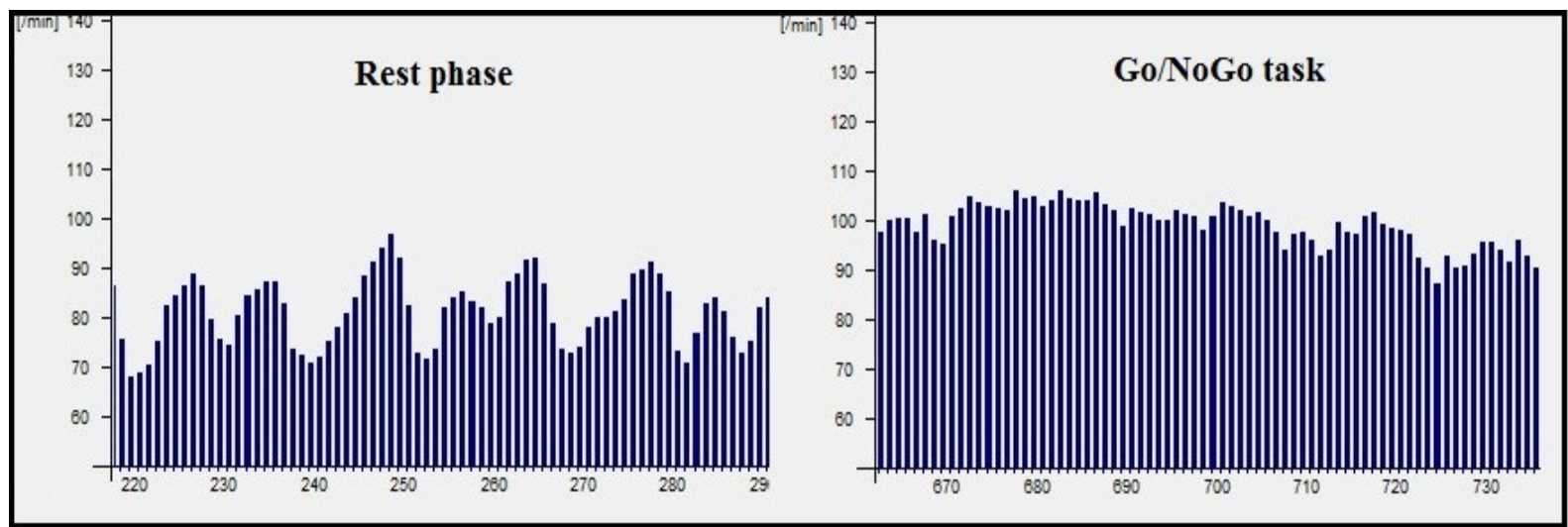

Fig. $1 \mathrm{HRV}$ in rest phase and during CPT in healthy subject indicates a physiological response of ANS

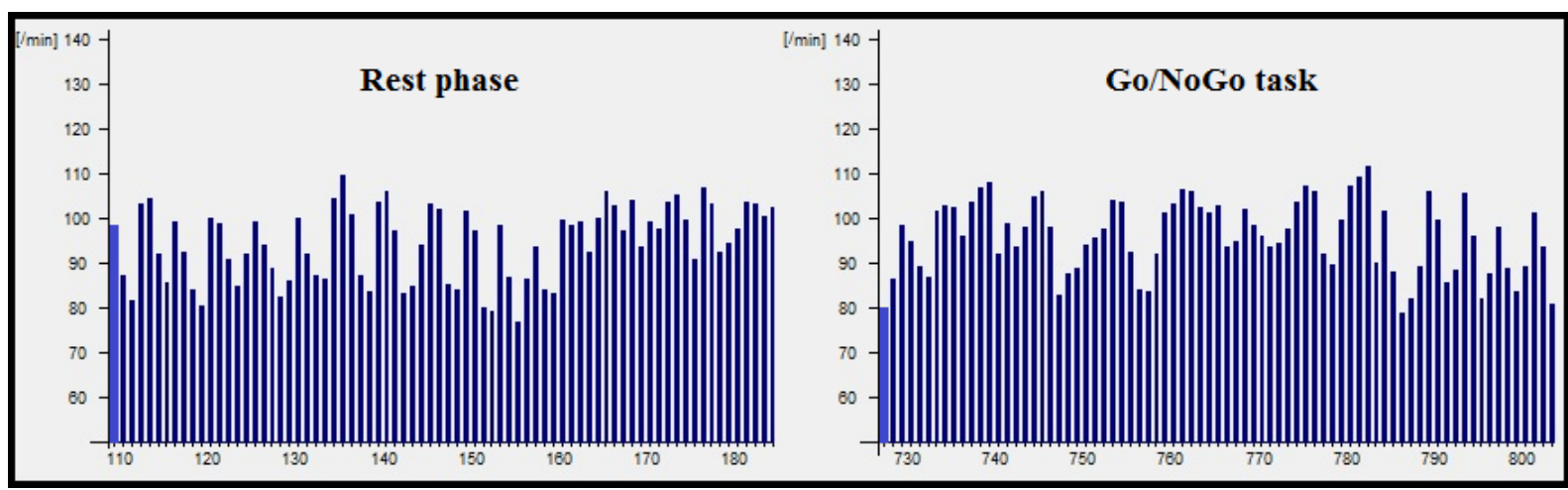

Fig. 2 Altered HRV in rest phase and during CPT in ADHD patient

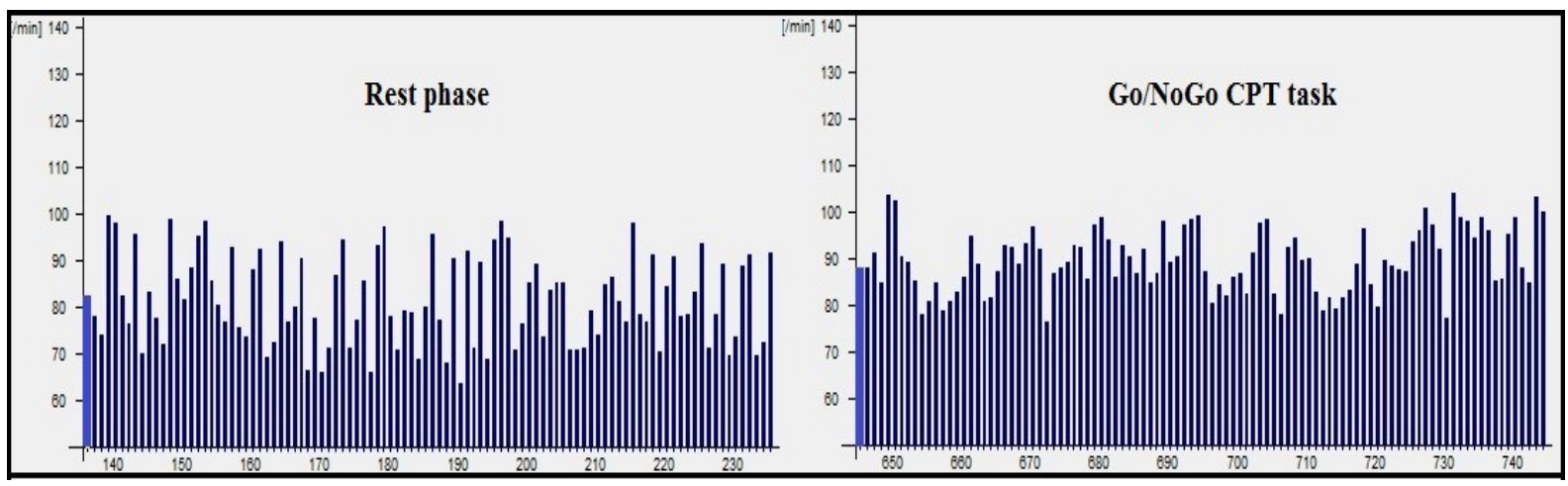

Fig. 3 Altered HRV in rest phase and during CPT in depressive patient 


\section{Electrodermal aktivity - index of sympathetic activity}

Electrodermal activity (EDA) is accepted as a noninvasive marker of sympathetic arousal in response to stress in psychophysiological research (Ionescu-Tirgoviște and Pruna, 1993; Jacobs et al., 1994). Value of skin conductance depends of amount of sweat produced by ecrine sweat glands regulationg by sympathetic nervous system. When the sweat duct is filled with sweat, more conductive area originates on the nonconductive corneu (Dawson et al., 2007). In our study, we assesed EDA in response to CPT in the same patient mentioned above (Figures 4,5,6). EDA amplitude $(\mu \mathrm{S})$ was evaluated in a percentage value from resting phase (5 min.) and the CPT response (5 min.). Our individual pilot results found the lowest EDA reactivity in ADHD patient (23,73\%) compared to depression $(58,06 \%)$ and heathy subject $(65,49 \%)$ indicating a potential sympathetic underarousal typical for externalizing psychopathology. Therefore, we suggest that electrodermal response to CPT could represent a biomarker for externalizing/internalizing psychopathology differences.
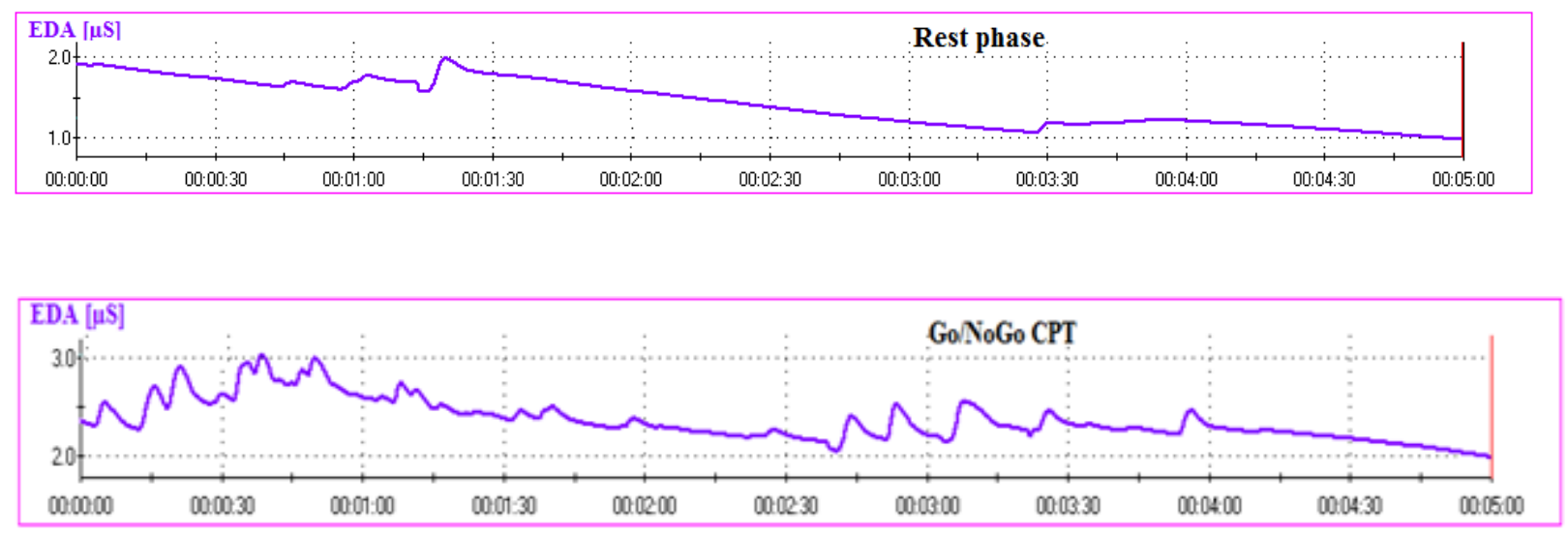

Fig. 4 Increased EDA in control subject indicating sympathetic arousal in response to stress
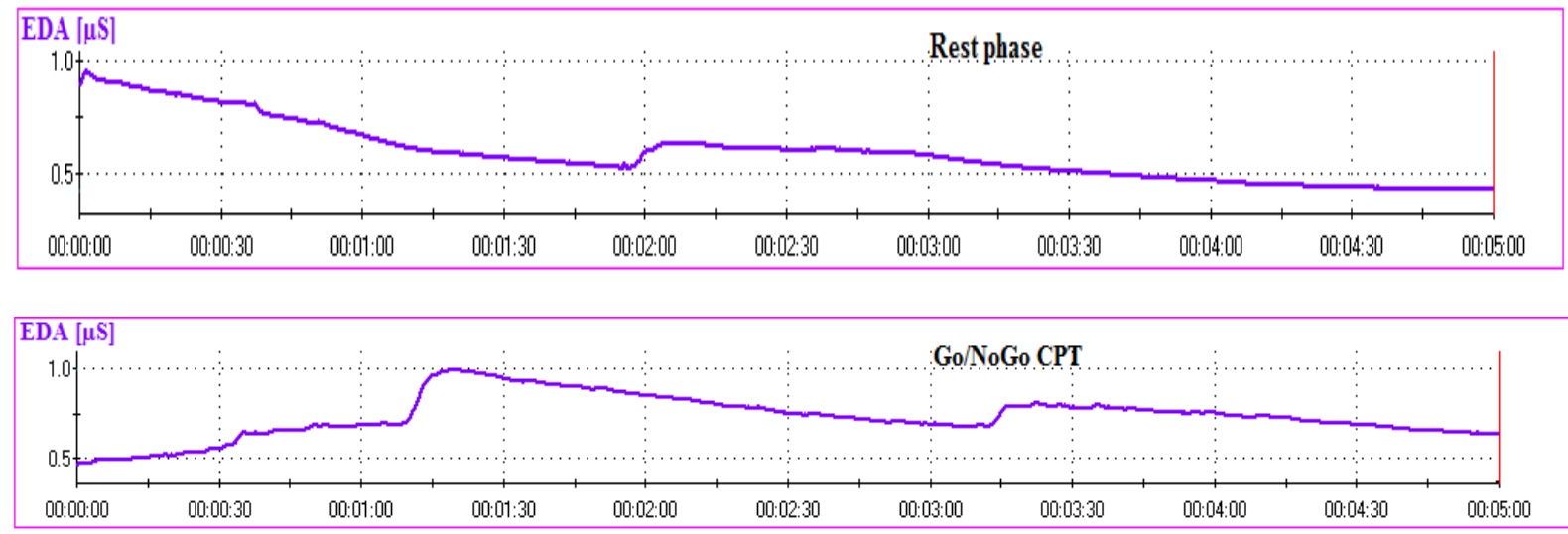

Fig. 5 EDA in ADHD patient indicating a potential sympathetic hypoarousal 

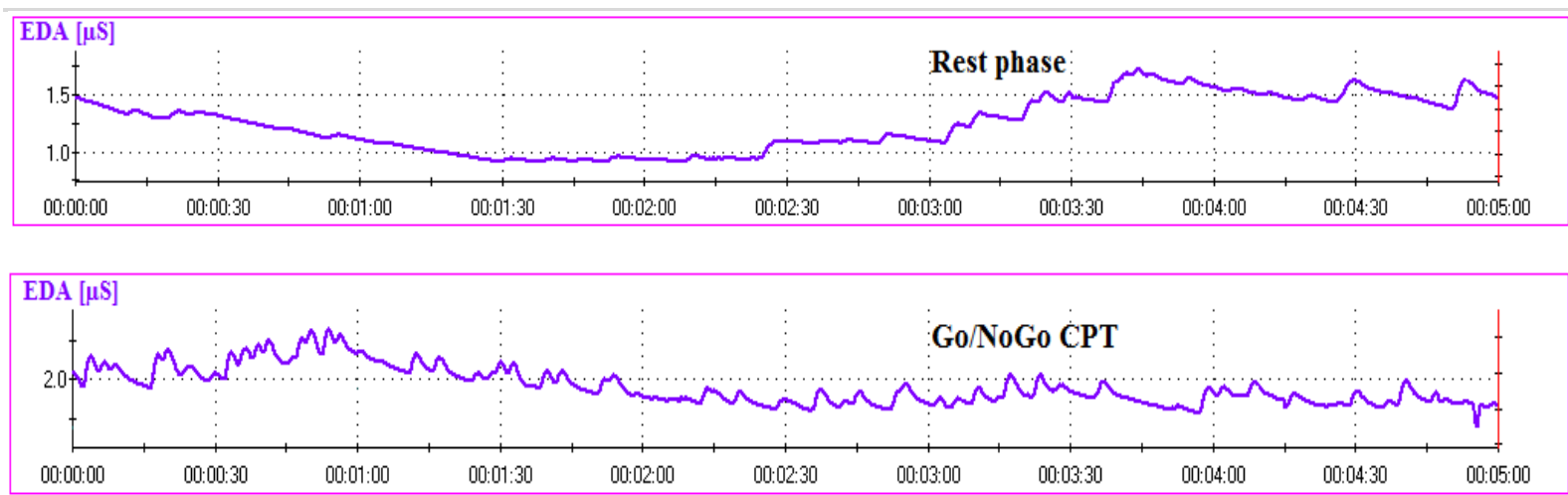

Fig. 6 EDA in depression patient indicating sympathetic arousal in response to stress

\section{Conclusion}

Go/NoGo CPT represents a neuropsychological test of vigilance and sustained attention, but it is not standard diagnostic tool in mental disorders. We suggest that diminished HRV and electrodermal activity in response to CPT could indicate abnormal autonomic regulation associated with higher risk of adverse health outcomes. It seems that complex psychophysiological approach may be useful in clinical application for differential diagnosis of mental disorders. Future research is needed.

\section{Acknowledgment}

The study was supported by VEGA 1/0087/14, VEGA 1/0059/13, BioMED (ITMS 26220220187).

\section{References}

ARON, A. R., FLETCHER, P. C., BULlMORE, E. T., SAHAKIAN, B. J., ROBBINS, T. W. Stop-signal inhibition disrupted by damage to right inferior frontal gyrus in humans. Nature Neuroscience, 2003, vol. 6, no. 2, p. 115-116.

BARRETT, P., EYSENCK, H. J., LUCKING, S. Reaction time and intelligence: A replicated study. Intelligence, 1986, vol. 10, p. 9-40.

BARKLEY, R. A. The ecological validity of laboratory and analogue assessments of ADHD symptoms. Journal of Abnormal Child Psychology, 1991, vol. 19, p. 149-178.

BARKLEY, R. A. Behavioral inhibition, sustained attention, and executive functions: Constructing a unifying theory of ADHD. Psychological Bulletin, 1997, vol. 121, no. 1, p. 65-94.

BERKSON, G., BAUMEISTER, A. Reaction time variability of mental defectives and normals. American Journal of Mental Deficiency, 1967, vol. 72, p. 262-266.

BERTSON, G. G., BIGGER, J. T. Jr, ECKBERG, D. L., GROSSMAN, P., KAUFMANN, P. G., MALIK, M., NAGARAJA, H. N., PORGES, S. W., SAUL, J. P., STONE, P. H., VAN DER MOLEN, M. W. Heart rate variability: origins, methods, and interpretive caveats. Psychophysiology, 1997, vol. 34, p. 623-48.

BORA, E., VAHIP, S., AKDENIZ, F. Sustained attention deficits in manic and euthymic patients with bipolar disorder. Progress in Neuro-Psychopharmacology \& Biological Psychiatry, 2006, vol. 30, p. 1097-1102. 
BORGER, N., VAN DER MEERE, J. J., RONNER, A., ALBERTS, E., GEURZEL, R., BOGTE, H. Heart rate variability and sustained attention in ADHD children. Journal of Abnormal Child Psycholy, 1999, vol. 27, p. 25-33.

BURCHFIELD, S. The stress responses: A new perspective. Psychosomatic Medicine, 1979, vol. 41, p. 661- 672.

CHAMBERS, C. D., BELlGROVE, M. A., STOKES, M. G., HENDERSON, T. R., GARAVAN, H., ROBERTSON, I. H., MORRIS, A. P., MATTINGLEY, J. B. Executive brake failure following deactivation of human frontal lobe. Journal of Cognitive Neuroscience, 2006, vol. 18, no. 3, p. 444-455.

CHI, D. S., NEUMANN, J. K., MOTA-MARQUEZ, M., DUBBERLEY, F. A. Effects of acute stress on lymphocyte beta 2 -adrenoceptors in white males. Journal of Psychosomatic Research, 1993, vol. 37, no. 7, p. 763-70.

CONNERS, C. K. Conners' Continuous Performance Test user's manual. 2000, Toronto, Canada: Multi-Health Systems.

DAWSON, M., SCHELL, A., FILION, D. The electrodermal system. In CACIOPPO, J., TASSINARY, L., BERNTSON, G. Handbook of psychophysiology, 2007, p. 159-181.

DIAMOND, A. Developmental time course in human infants and infant monkeys, and the neural bases of, inhibitory control in reaching. Annals of the New York Academy Science, 1990, vol. 608, p. 637-676.

DELAHANTY, D. L., DOUGALL, A. L., SCHMITZ, J. B., HAWKEN, L., TRAKOWSKI, J. H., JENKINS, F. J., BAUM, A. Time course of natural killer cell activity and lymphocyte proliferation inresponse to two acute stressors in healthy men. Health Psychology, 1996, vol. 15, no. 1, p. 48-55.

DREWE, E. A. Go-no go learning after frontal lobe lesions in humans. Cortex, 1975, vol. 11, no. 1, p. 8-16.

EISENBERG, J., RICHMAN, R. Heart Rate Variability during a Continuous Performance Test in Children with Problems of Attention. The Israel journal of psychiatry and related science, 2011, vol. 48, no. 1, p. 19-24.

EL-SHEIKH, M., KOUROS, C. D., ERATH, S., CUMMINGS, E. M., KELLER, P., STATON, L. Marital conflict and children's externalizing behavior: Interactions between parasympathetic and sympathetic nervous system activity. Monographs of the Society for Research in Child Development, 2009, vol. 74, no. 1, p. 1-79.

FLODEN, D., STUSS, D. T. Inhibitory control is slowed in patients with right superior medial frontal damage. Journal of Cognitive Neuroscience, 2006, vol. 18, no. 11, p. 1843-1849.

GARAVAN, H., ROSS, T. J., STEIN, E. A. Right hemispheric dominance of inhibitory control: An event-related functional MRI study. Proceeding of the National Academy of Sciences USA, 1999, vol. 96, no. 14, p. 83018306.

GEURTS, H. M., BEGEER, S., STOCKMANN, L. Brief report: Inhibitory control of socially relevant stimuli in children with high functioning autism. Journal of Autism and Developmental Disorders, 2009, vol. 39, p. 16031607.

GODEFROY, O., ROUSSEAUX, M. Divided and focused attention in patients with lesion of the prefrontal cortex. Brain and Cognition, 1996, vol. 30, no. 2, p. 155-174.

GOMEZ-GUERRERO, L., MARTIN, C. D., MAIRENA, M. A., DI MARTINO, A., WANG, J., MENDELSOHN, A. L., DREYER, B. P., ISQUITH, P. K., GIOIA, G., PETKOVA, E., CASTELLANOS, F. X. Response-time variability is 
related to parent ratings of inattention, hyperactivity, and executive function. Journal of Attention Disorders, 2011, vol. 15, p. 572-582.

GUALTIERI, C. T., JOHNSON, L. G. ADHD: Is Objective Diagnosis Possible? Psychiatry (Edgmont), 2005, vol. 2, no. 11 p. 44-53.

HALPERIN, J. M., WOLF, L. E., GREENBLATT, E. R., YOUNG, G. Subtype analysis of commission errors on the continuous performance test in children. Developmental Neuropsychology, 1991, vol. 7, p. 207-217.

HANSEN, A. L., JOHNSEN, B. H., THAYER, J. F. Vagal influence on working memory and attention. International Journal of Psychophysiology, 2003, vol. 40, p. 306-313.

IONESCU-TIRGOVIŞTE, C., PRUNA, S. The pattern of the electrodermal activity as indicator of stress related reaction. Romanian journal of physiology, 1993, vol. 30, no. 3-4, p. 207-218.

JACOBS, S. C., FRIEDMAN, R., PARKER, J. D., TOFLER, G. H., JIMENEZ, A. H., MULLER, J. E., BENSON, H., STONE, P. $\mathrm{H}$. Use of skin conductance changes during mental stress testing as an index of autonomic arousal in cardiovascular research. American Heart Journal, 1994, vol. 128, p. 1170-1177.

JENSEN, A. R. The importance of intraindividual variation in reaction time. Personality and Individual Differences, 1992, vol. 13, p. 869-881.

JAVORKA, M., TURIANIKOVA, Z., TONHAJZEROVA, I., JAVORKA, K., BAUMERT, M. The effects of orthostasis on recurrence quantification analysis of heart rate and blood pressure dynamics. Physiological Measurement, 2009, vol. 30, no. 1, p. 29- 41

KAISER, S., ROTH, A., RENTROP, M., FRIEDERICH, H.C., BENDER, S., WEISBROD, M. Intra-individual reaction time variability in schizophrenia, depression and borderline personality disorder. Brain and Cognition, 2008, vol. 66, p. 73-82.

KARALUNAS, S. L., GEURTS, H. M., KONRAD, K., BENDER, S., NIGG, J. T. Annual Research Review: Reaction time variability in ADHD and autism spectrum disorders: measurement and mechanisms of a proposed transdiagnostic phenotype. Journal of Child Psychology and Psychiatry, 2004, vol. 55, no. 6, p. 685-710.

LANE, R. D., MCRAE, K., REIMAN, E. M., CHEN, K., AHERN, G. L., THAYER, J. F. Neural correlates of heart rate variability during emotion. NeuroImage, 2009 , vol. 44, no. 1, p. 213-222.

MARTINMÄKI, K., RUSKO, H., SAALASTI, S., KETTUNEN, J. Ability of short-time Fourier transform method to detect transient changes in vagal effect on hearts: a pharmacological blocking study. American Journal of Physiology Heart and Circulatory Physiology, 2006, vol. 290, p. 258-9.

MARTINEZ-LAVIN, M. Stress, the stress response system, and fibromyalgia. Arthritis Research \& Therapy, 2007, vol. 9, p. 216.

McGEE, R. A., CLARK S. E., SYMONS, D. K. Does the Conners' Continuous Performance Test Aid in ADHD Diagnosis? Journal of Abnormal Child Psychology, 2000, vol. 28, no. 5, p. 415-424.

McCORRY, L. K. Physiology of the Autonomic Nervous System. American Journal of Pharmaceutical Education, 2007, vol. 71, no. 4, p. 78. 
MRAVEC, B., ONDICOVA, K.., VALASKOVA, Z., GIDRON, Y., HULIN, I. Neurobiological principles in the etiopathogenesis of disease: when diseases have a head. Medical Science Monitor, 2009, vol. 15, no. 1, p. 616.

MRAVEC B., ZUCHA I. Neuroendokrínne reakcie sprevádzajúce strach. Psychiatria, 2006, vol. 13, no. 1-2, p. 614.

MOSTOFSKY, S. H., SCHAFER, J. G., ABRAMS, M. T., GOLDBERG, M. C., FLOWER, A. A., BOYCE, A., COURTNEY, S. M., CALHOUN, V. D., KRAUT, M. A., DENCKLA, M. B., PEKAR, J. J. fMRI evidence that the neural basis of response inhibition is task-dependent. Brain Research. Cognitive Brain Research, 2003, vol. 17, no. 2, p. 419430.

NELSON, E. B., SAX, K. W., STRAKOWSKI, S. M. Attentional performance in patients with psychotic and nonpsychotic major depression and schizophrenia. The American Journal of Psychiatry, 1998, vol. 155, no. 1, p. 137-139.

NIGG, J. T. The ADHD response-inhibition deficit as measured by the stop task: replication with DSM-IV combined type, extension, and qualification. Journal of Abnormal Child Psychology, 1999, vol. 27, p. 393-402.

OBRADOVIC, J., BUSH, N. R., STAMPERDAHL, J., ADLER, N. E., BOYCE, W. T. Biological sensitivity to context: The interactive effects of stress reactivity and family adversity on socioemotional behavior and school readiness. Child Development., 2010, vol. 81, no. 1, p. 270-289.

PICTON, T. W., STUSS, D. T., ALEXANDER, M. P., SHALLICE, T., BINNS, M. A., GILLINGHAM, S. Effects of focal frontal lesions on response inhibition. Cerebral Cortex, 2006, vol. 17, no. 4, p. 826-38.

PORTA, A., DADDIO, G., BASSANI, T., MAESTRI, R., PINNA, G. D. Assessment of cardiovascular regulation through irreversibility analysis of heart period variability: a 24 hours Holter study in healthy and chronic heart failure populations. Philosophical Transactions of the Royal Society A Mathematical, Physical \& Engineering Sciences, 2009, vol. 367, no. 1892, p. 1359-1375.

RUBIA, K., RUSSELL, T., OVERMEYER, S., BRAMMER, M. J., BULLMORE, E. T., SHARMA, T., SIMMONS, A., WILLIAMS, S. C., GIAMPIETRO, V., ANDREW, M., TAYLOR, E. Mapping motor inhibition: conjunctive brain activations across different versions of go/no-go and stop tasks. NeuroImage, 2001, vol. 13 , no. 2, p. 250-261.

SELYE, H. A syndrome produced by diverse noxious agents. Nature, 1936, vol. 32, no. 1, p. 38.

SIMMONDS, D. J., PEKAR, J. J., MOSTOFSKY, S. H. Meta-analysis of Go/No go tasks demonstrating that fMRI activation associated with response inhibition is task-dependent. Neuropsychologia, 2008, vol. 15, no. 46, no. 1, p. 224-232.

SINZIG $\_$J., MORSCH, D., BRUNING, N., SCHMIDT 2 M. H., LEHMKUH, G. Inhibition, flexibility, working memory and planning in autism spectrum disorders with and without comorbid ADHD-symptoms. Child Adolescent Psychiatry and Mental Health, 2008, vol. 2, no. 1, p. 4

SHUCARD,_J. L., McCABE, D. C., SZYMANSKI, H. An event related potential study of attention deficits in posttraumatic stress disorder during auditory and visual Go/NoGo continuous performance tasks. Biological Psychology, 2008, vol. 79, no. 2, p. 223-233. 
STEIN, P. K., KLEIGER, R. E. Insights from the study of heart rate variability. Annual Review of Medicine, 1999; vol. 50, p. 249-261.

TASK FORCE OF THE EUROPEAN SOCIETY OF CARDIOLOGY AND THE NORTH AMERICAN SOCIETY OF PACING AND ELECTROPHYSIOLOGY. Heart rate variability. Standards of measurement, physiological interpretation, and clinical use. Circulation, 1996, vol. 93, no. 5, p. 1043-1065.

THAYER J. F., HANSEN A. L., SAUS-ROSE, E., JOHNSEN, B. H. Heart rate variability, prefrontal neural functions, and cognitive performance: the neurovisceral integration perspective on self-regulation, adaptation, and health. Annals of Behavioral Medicine, 2009, vol. 37, no. 2, p. 141-153.

THOMALLA, G., JONAS, M., BÄUMER, T., SIEBNER, H. R., BIERMANN-RUBEN, K., GANOS, C., ORTH M., HUMMEL C., GERLOFF, C., MÜLLER-VAHL, K., SCHNITZLER, A., MÜNCHAU, A. Costs of control: decreased motor cortex engagement during a Go/NoGo task in Tourette's syndrome. Brain, 2014, vol. 137, p. 122-136.

VAN RAVENSWAAIJ-ARTS, C. M., KOLLEE, L. A. A., HOPMAN, J. C. W., STOELINGA, G. B. A., VAN GEIJN, H. P. Heart rate variability. Annals of Internal Medicine, 1993, vol. 118, p. 436-447.

VERTE, S., GEURTS, H. M., ROEYERS, H., OOSTERLAAN, J., SERGEANT, J. A. Executive functioning in children with autism and Tourette syndrome. Development and Psychopathology, 2005, vol. 17, p. 415-445.

VISNOVCOVA, Z., MESTANIK, M., JAVORKA, M., MOKRA, D., GALA, M., JURKO, A., CALKOVSKA, A., TONHAJZEROVA, I. Complexity and time asymmetry of heart rate variability are altered in acute mental stress. Physiological Measurement, 2014, vol. 35, no. 7, p. 1319-1334.

WAHLSTEDT, C. Neuropsychological deficits in relation to symptoms of ADHD: independent contributions and interactions. Child Neuropsychology, 2009, vol. 15, no. 262-279.

WAHLSTEDT, C., THORELL, L. B., BOHLIN, G. Heterogeneity in ADHD: neuropsychological pathways, comorbidity and symptom domains. Journal of Abnormal Child Psychology, 2009, vol. 37, p. 551-564.

WILLIAMS, B. R., PONESSE, J. S., SCHACHAR, R. J., LOGAN, G. D., TANNOCK, R. Development of inhibitory control across the life span. Developmental Psychology, 1999, vol. 35, p. 205-213.

YU, F., YE, R., SUN, S., CARRETIE, L., ZHANG, L., DONG, Y., ZHU, C., LUO, Y., WANG, K. Dissociation of neural substrates of response inhibition to negative information between implicit and explicit facial Go/Nogo tasks: Evidence from an electrophysiological study. PLOS ON, 2014, vol. 9, no. 10, p. 1-10.

Received 15. January 2015; Revised 22 Feb. 2015-06 March 2015; Accepted 07 March 2015 